\title{
Pikiran Negatif dan Dampaknya Bagi Peserta Didik Ditinjau dari Persepektif Teori Kognitif
}

\author{
Oktovianus O., James B., Juprianto J.
}

\begin{abstract}
Abstrak
Tulisan ini bertujuan untuk menjelaskan peranan pikiran negatif bagi peserta didik ditinjau dari perspektif teori kognitif dan Alkitab. Melalui pembelajaran $5 \mathrm{P}$ diharapkan peserta didik mengalami perubahan paradigma berpikir dari negatif ke positif supaya dapat mengambil keputusan dan perilaku yang benar dalam masa pertumbuhan mereka. Teori Jean Piaget digunakan untuk merumuskan pembelajaran yang sesuai dengan usia dan perkembangan peserta didik. Teori ini berhubugan juga dengan motivasi peserta didik dalam berperilaku.
\end{abstract}

Kata-kata kunci: kognitif, Jean Piaget, motivasi, jahat, baik

\section{Pendahuluan}

Teori belajar kognitif merupakan suatu teori belajar yang lebih mementingkan proses belajar daripada hasil belajar. Teori kognitf pada awalnya dikemukakan oleh Dewey, dilanjutkan oleh Jean Piaget, Kohlberg, Damon, Mosher, Perry dan lain-lain, yang membicarakan tentang perkembangan kognitif dalam kaitannya dengan belajar.

Jean Piaget lahir pada tanggal 1989 di Neuhatel, Swiss, Ayahnya adalah seorang profesor dengan spesialis ahli sejarah abad pertengahan, ibunya adalah seorang yang dinamis, inteligen dan takwa. Waktu mudanya Piaget sangat tertarik pada alam, ia suka mengamati burung-burung, ikan dan binatang-binatang di alam bebas. Itulah sebabnya ia sangat tertarik pada pelajaran biologi di sekolah. Perkembangan pemikiran Piaget banyak dipengaruhi oleh Samuel Cornut sebagai bapak pelindungnya, seorang ahli dari Swiss. Cornut mengamati bahwa Piaget selama masa remaja sudah terlalu memusatkan pikirannya pada biologi, menurutnya ini dapat membuat pikiran Piaget menjadi sempit.

Oleh karena itu Cornut ingin mempengaruhi Piaget dengan memperkenalkan filsafat. Setelah mempelajari dan tertarik dengan ilmu biologi, lalu kemudian ia mengalihkan fokusnya ke perkembangan intelektual (termasuk tahap perkembangan anaknya sendiri) dan mulai pengaruh besar pada konsep kognitif dalam perkembangan kepribadian. Piaget, ahli biologi yang memperoleh nama sebagai psikolog anak karena mempelajari perkembangan inteligensi, menghabiskan ribuan jam mengamati anak yang sedang bermain dan menanyakan mereka tentang perilaku dan perasaannya. Ia tidak mengembangkan teori sosialisasi yang komprehensif, tetapi memusatkan perhatian pada bagaimana anak belajar, berbicara, berfikir, bernalar dan akhirnya membentuk pertimbangan moral. Bersama dengan istrinya yang bernama Valentine.

Salah satu aspek yang sangat penting untuk diketahui dan dipahami dari perkembangan anak usia dasar adalah aspek kogntif. Perkembangan kognitif merupakan suatu perkembangan yang sangat komprehensif yaitu berkaitan dengan kemampuan 
berfikir, seperti kemampuan bernalar, mengingat, menghafal, memecahkan masalahmasalah nyata, beride dan kreatifitas.

\section{Kajian Teori}

\section{Perkembangan Kognitif Menurut Jean Pieget}

Piaget lebih menitik beratkan pembahasannya pada struktur kognitif. Ia meneliti dan menulis subjek perkembangan kognitif ini dari tahun 1927 sampai 1980. Berbeda dengan para ahli-ahli psikologi sebelumnya. Ia menyatakan bahwa cara berfikir anak bukan hanya kurang matang dibandingkan dengan orang dewasa karena kalah pengetahuan, tetapi juga berbeda secara kualitatif. Menurut penelitiannya juga bahwa tahap-tahap perkembangan intelektual individu serta perubahan umur sangat mempengaruhi kemampuan individu mengamati ilmu pengetahuan. ${ }^{1}$ Menurut Piaget, anak dilahirkan dengan beberapa skemata sensorimotor, yang memberi kerangka bagi interaksi awal anak dengan lingkungannya. Pengalaman awal si anak akan ditentukan oleh skemata sensorimotor ini. Dengan kata lain, hanya kejadian yang dapat diasimilasikan ke skemata itulah yang dapat direspons oleh si anak, dan karenanya kejadian itu akan menentukan batasan pengalaman anak. Tetapi melalui pengalaman, skemata awal ini dimodifikasi. Setiap pengalaman mengandung elemen unik yang harus di akomodasi oleh struktur kognitif anak. Melalui interaksi dengan lingkungan, struktur kognitif akan berubah, dan memungkinkan perkembangan pengalaman terus-menerus.

Menurut Piaget aspek perkembangan kognitif meliputi empat tahap, yaitu:

a. Tahap sensorimotor (usia 0-2 tahun). individu memahami sesuatu atau tentang dunia dengan mengkoordinasikan pengalaman-pengalaman sensoris, (seperti melihat, dan mendengar) dan dengan tindakan-tindakan motorik fisik. Dengan kata lain, pada usia ini individu dalam memahami sesuatu yang berada di luar dirinya melalui gerakan, suara atau tindakan yang dapat diamati atau dirasakan oleh alat inderanya. Selanjutnya sedikit demi sedikit individu mengembangkan kemampuannya untuk membedakan dirinya dengan bendabenda lain.

b. Tahap pra-operasional (usia 2-7 tahun). Individu mulai melukiskan dunia melalui tingkah laku dan kata-kata. Tetapi belum mampu untuk melakukan operasi, yaitu melakukan tindakan mental yang diinternalisasikan atau melakukan tindakan mental terhadap apa yang dilakukan sebelumnya secara fisik. Pada usia ini individu mulai memiliki kecakapan motorik untuk melakukan sesuatu dari apa yang dilihat dan didengar, tetapi belum mampu memahami secara mental (makna atau hakekat) terhadap apa yang dilakuaknnya tersebut.

c. Tahap operasional konkret (usia 7-11 tahun). Individu mulai berpikir secara logis tentang kejadian-kejadian yang bersifat konkret. Individu sudah dapat membedakan benda yang sama dalam kondisi yang berbeda.

d. Tahap operasional formal (11 tahun ke atas). Sementara Salvin menjelaskan bahwa pada operasional formal terjadi pada usia 11 sampai dewasa awal. Pada masa ini individu mulai memasuki dunia "kemungkinan" dari dunia yang sebenarnya atau individu mengalami perkembangan penalaran abstrak. Individu dapat berpikir secara abstrak, lebih logis dan idealis.

\footnotetext{
${ }^{1}$ Rovi Pahliwandari, "Penerapan Teori Pembelajaran Kognitif Dalam Pembelajaran Pendidikan Jasmani Dan Kesehatan,” Jurnal Pendidikan Olahraga 5, no. 2 (March 18, 2017): 154-64, https://doi.org/10.31571/jpo.v5i2.383.
} 
Implementasi Teori Perkembangan Kognitif Piaget Dalam Pembelajaran, adalah: ${ }^{2}$

a. Bahasa dan cara berfikir anak berbeda dengan orang dewasa. Oleh karena itu guru mengajar dengan menggunakan bahasa yang sesuai dengan cara berfikir anak.

b. Anak-anak akan belajar lebih baik apabila dapat menghadapi lingkungan dengan baik. Guru harus membantu anak agar dapat berinteraksi dengan lingkungan sebaikbaiknya.

c. Bahan yang harus dipelajari anak hendaknya dirasakan baru tetapi tidak asing.

Teori belajar Piaget dalam aplikasi praktisnya mementingkan keterlibatan siswa dalam proses belajar mengajar, karena hanya dengan melibatkan atau mengaktifkan siswa, maka proses asimilasi dan akoomodasi pengetahuan dapat terjadi dengan baik. Secara umum pengaplikasian teori piaget dalam kegiatan pembelajaran biasanya mengikuti pola berikut:

a. Menentukan tujuan-tujuann instruksional

b. Memilih amteri pelajaran

c. Menentukan topic-topik yang mungkin dipelajari secara aktif oleh siswa (dengan bimbingan minimum dari guru).

d. Menentukan dan merancang kegiatan belajar yang cocok untuk topic-topik yang akan dipelajari siswa.

e. Mempersiapkan berbagai pertanyaan yang dapat memacu kreativitas siswa untuk berdiskusi atau bertanya.

f. Mengevaluasi proses dan hasil belajar.

\section{Metode}

Metode penulisan makalah ini adalah metode kualitatif deskripstif. Gagasan atau ide penulis dituangkan dalam tulisan yang dilengkapi dengan literatur yang berhubungan dengan topik yang dikaji. ${ }^{3}$ Selanjutnya kajian eksposisi Alkitab menjabarkan nas yang diambil untuk mendukung teori-teori yang ada. ${ }^{4}$ Kajian teologis didasarkan pada pemikiran sistematis dasar teologi yang teguh karangan Daniel Ronda. ${ }^{5}$ Data-data yang terkumpul dibangkitkan menjadi data-data yang bisa dijelaskan secara mendalam dengan melengkapi referensi-referensi yang sesuai dengan tujuan penulisan makalah ini. ${ }^{6}$

Tujuan penulisan makalah ini adalah menjelaskan dampak pikiran negatif ditinjau dari perspektif kognitif yang dipraktikkan melalui $5 \mathrm{P}$ (Penghubung, Pelajaran, Penerapan, Perubahan, dan Penutup). Bagian ini adalah aktivitas belajar siswa di kelas yang diharapkan memberikan pengaruh untuk perubahan pola piker negatif menjadi pola piker yang positif, membangun, dan mengubahkan. Semuanya itu dapat dilakukan dalam kebenaran firman Tuhan. Model pembelajaran kooperatif adalah jawaban untuk

\footnotetext{
${ }^{2}$ Sutarto Sutarto, “Teori Kognitif Dan Implikasinya Dalam Pembelajaran," Islamic Counseling: Jurnal Bimbingan Konseling Islam 1, no. 2 (December 28, 2017): 1-26, https://doi.org/10.29240/jbk.v1i2.331.

${ }^{3}$ Hengki Wijaya, Analisis Data Kualitatif Ilmu Pendidikan Teologi (Makassar: Sekolah Tinggi Theologia Jaffray Makassar, 2018).

${ }^{4}$ Hengki Wijaya, Metode Penelitian Pendidikan Teologi (Makassar: Sekolah Tinggi Theologia Jaffray Makassar, 2013).

${ }^{5}$ Daniel Ronda, Dasar Teologi Yang Teguh: Panduan Teologi Sistematika Di Perguruan Tinggi (Makassar: Sekolah Tinggi Theologia Jaffray Makassar, 2013).

${ }^{6}$ Hengki Wijaya and Helaluddin Helaluddin, Analisis Data Kualitatif Sebuah Tinjauan Teori \& Praktik (Makassar: Sekolah Tinggi Theologia Jaffray Makassar, 2019).
} 
melaksanakan $5 \mathrm{P}$ ini karena berkelompok dan di dalamnya ada kerjasama, kolaborasi, dan berbagi pengalaman. ${ }^{7}$

\title{
Pembahasan
}

\author{
Kegiatan pembelajaran dengan menggunakan $5 \mathrm{P}$ dalam ilmu Pendidikan \\ Kisah Para Rasul 5:1-11 (Motivasi yang salah)
}

\section{Penghubung}

Pengertian kognitif secara umum adalah kemampuan atau potensi intelektual sesorang dalam berpikir, mengetahui, dan memecahkan masalah. Dengan demikian, kognitif berkaitan dengan persoalan yang menyangkut kemampuan untuk mengembangkan kemampuan otak (akal rasional). Teori kognitif dikembangkan oleh Jean Piaget, seorang psikolog Swiss yang hidup tahun 1896-1980. Berpendapat bahwa manusia membangun kemampuan kognitifnya melalui tindakan yang termotivasi dengan sendirinya terhadap lingkungan.

Pada bagian ini apakah kita pernah berpikir negatif, berniat tidak baik, dan berperilaku buruk sebagai akibat apa yang kita pikirkan? Tentu setipa manusia pernah melakukannya. Hawa pun pernah berpikir meraba buah pohon kehidupan. Pikiran yang jahat memengaruhi sikap dan karakter seseorang. Karakter adalah jati diri seseorang yang sudah menjadi habitus yang dipengaruhi oleh jiwa, akhlak, dan moral yang baik atau jahat. ${ }^{8}$ Sebagai contoh motivasi siswa untuk belajar untuk mendapatkan prestasi, atau hasil belajar yang baik. Bila niat siswa tidak baik maka sikapnya akan malas, rajin bolos, dan tidak peduli dengan tanggung jawabnya sebagai siswa. Apa yang mendorong sesorang untuk berhasil dan menghasilkan nilai atau reward disebut sebagai motivasi. ${ }^{9}$

\section{Pelajaran}

Ada seorang lain yang bernama Ananias. Ia beserta isterinya Safira menjual sebidang tanah. _2 Dengan setahu isterinya ia menahan sebagian dari hasil penjualan itu dan sebagian lain dibawa dan diletakkannya di depan kaki rasul-rasul. $\underline{\mathbf{3}}$ Tetapi Petrus berkata: "Ananias, mengapa hatimu dikuasai Iblis, sehingga engkau mendustai Roh Kudus dan menahan sebagian dari hasil penjualan tanah itu? $\underline{4}$ Selama tanah itu tidak dijual, bukankah itu tetap kepunyaanmu, dan setelah dijual, bukankah hasilnya itu tetap dalam kuasamu? Mengapa engkau merencanakan perbuatan itu dalam hatimu? Engkau bukan mendustai manusia, tetapi mendustai Allah." $\underline{\mathbf{5}}$ Ketika mendengar perkataan itu rebahlah Ananias dan putuslah nyawanya Maka sangatlah ketakutan ${ }^{\mathrm{f}}$ semua orang yang mendengar hal itu. $\underline{6}$ Lalu datanglah beberapa orang muda; mereka mengapani mayat itu, mengusungnya ke luar dan pergi menguburnya. 7 Kira-kira tiga jam kemudian masuklah isteri Ananias, tetapi ia tidak tahu apa yang telah terjadi. $\underline{8}$ Kata Petrus kepadanya: "Katakanlah kepadaku, dengan harga sekiankah tanah itu kamu jual?" Jawab

\footnotetext{
${ }^{7}$ Hengki Wijaya and Arismunandar Arismunandar, "Pengembangan Model Pembelajaran Kooperatif Tipe STAD Berbasis Media Sosial,” Jurnal Jaffray 16, no. 2 (October 6, 2018): 175-96, https://doi.org/10.25278/jj71.v16i2.302.

${ }^{8}$ Hengki Wijaya and Helaluddin Helaluddin, "Hakikat Pendidikan Karakter," 2018, https://repository.sttjaffray.ac.id/id/publications/269450/hakikat-pendidikan-karakter.

${ }^{9}$ Sifra Sahiu and Hengki Wijaya, "Hubungan Motivasi Belajar Ekstrinsik Terhadap Hasil Belajar Psikomotorik Pada Mata Pelajaran Agama Kristen Kelas V Di SD Zion Makassar,” Jurnal Jaffray 15, no. 2 (September 22, 2017): 231, https://doi.org/10.25278/jj71.v15i2.262.
} 
perempuan itu: "Betul sekian. 9 Kata Petrus: "Mengapa kamu berdua bersepakat untuk mencobai Roh Tuhan? Lihatlah, orang-orang yang baru mengubur suamimu berdiri di depan pintu dan mereka akan mengusung engkau juga ke luar." 10 Lalu rebahlah perempuan itu seketika itu juga di depan kaki Petrus dan putuslah nyawanya. Ketika orang-orang muda itu masuk, mereka mendapati dia sudah mati, lalu mereka mengusungnya ke luar dan menguburnya di samping suaminya. 11 Maka sangat ketakutanlah seluruh jemaat dan semua orang yang mendengar hal itu.

Setiap kelompok membaca firman tersebut serta memahami, merasakan, dan melakukan apa yang didapat dari firman tersebut. Menuliskan setiap tokoh-tokoh yang ada dalam teks firman Tuhan pada sticker note dan menempelkannya pada papan tulis.

Tokoh-tokoh di dalamnya adalah Barnabas yang melakukan niat baiknya tanpa niat yang jahat. Tokoh Ananias dan Safira yang melihat dengan matanya apa yang dilakukan Barnabas juga ikut termotivasi untuk melakukan hal yang sama, namun niatnya adalah jahat di hadapan Tuhan. Mereka menginginkan pujian. Pikiran mereka licik, ingin mendapatkan pujian, dan penuh perhitungan.

Pelajaran penting bagi pemuda adalah niatan yang jahat dari pikiran telah membuat seorang pemuda berdosa. Apabila itu telah dilakukan maka tentunya tidak aka nada pertumbuhan rohani. Malahan yang ada kemerosotan moral, dan krisis rohani. ${ }^{10}$ Pemberian Ananias dan Safira adalah penyembahan yang tidak berkenan kepada Allah. Akibatnya tidak hanya kematian rohani tetapi juga kematian fisik terjadi. Penyembahan yang benar kepada Allah adalah seluruh hidup kita berkenan kepada Allah, bukan sebagian. Sikap hormat kepada Allah tercermin melalui perbuatan, dan penyembahan kepada Allah. ${ }^{11}$

Sebagai ciptaan yang baru maka dosa (niat jahat) tidak menjadi bagian hidup kita, atau gaya hidup orang percaya, namun natur manusia baru adalah bagian kita yang terusmenerus diperbarui oleh Roh Kudus. ${ }^{12}$ Roh Kudus berperan sebagai pribadi yang memberikan pengaruh untuk perubahan perilaku seseorang. ${ }^{13}$

\section{Penerapan}

Setiap kelompok berdiskusi di meja masing-masing, bertukar pendapat dengan kelompok masing-masing. Hasil dari diskusi itu disimpulkan dan satu siswa dari perwakilan tiaptiap kelompok maju kedepan dan menyampaikan hasil diskusinya. Dalam kesaksian ini diharapkan peserta didik dapat mengungkapkan kisahnya yang serupa dengan kejadian Ananias dan Safira dan menyadarinya sebagai suatu dosa atau kejahatan di hadapan Tuhan.

\section{Perubahan}

$>$ Siswa mengamati cerita Alkitab melalui video singkat. Melalui video diharapkan peserta semakin memamhami secara mendalam maksud kebenaran firman Tuhan

\footnotetext{
${ }^{10}$ Jonathan Matheus and Elisabet Selfina, "Peran Pembina Remaja Bagi Perkembangan Perilaku Remaja Di Gereja Kemah Injil Indonesia Tanjung Selor Kalimantan Utara," Jurnal Jaffray 13, no. 1 (January 31, 2015): 1-22, https://doi.org/10.25278/jj71.v13i1.3.

${ }^{11}$ Hengki Wijaya, "Ulasan Buku: Whatever Happened To Worship A Call To True Worship," Jurnal Jaffray 15, no. 1 (March 19, 2017): 148, https://doi.org/10.25278/jj71.v15i1.241.

${ }^{12}$ Hengki Wijaya, "Pengenaan Manusia Baru Di Dalam Kristus: Natur, Proses, Dan Fakta Serta Implikasi Teologis Dan Praktisnya,” Jurnal Jaffray 14, no. 1 (March 22, 2016): 109, https://doi.org/10.25278/jj71.v14i1.194.

${ }^{13}$ Matheus and Selfina, "Peran Pembina Remaja Bagi Perkembangan Perilaku Remaja Di Gereja Kemah Injil Indonesia Tanjung Selor Kalimantan Utara."
} 
untuk dilaksanakan. Dalam video terlihat jelas pikiran Ananias dan Safira yang jahat dan dipenuhi oleh keingginan pujian dari para Rasul.

Penutup

$>$ Menyanyikan sebuah lagu sebagai pujian bagi Allah dan relevan dengan kebutuhan peserta didik. ${ }^{14}$

Berdoa

\section{Kesimpulan}

Kisah Ananias dan Safira yang berakhir tragis memberikan penyadaran bahwa berpikir jahat, dan niat hati yang ingin mendapatkan pujian dapat berakibat kehilangan keselamatan atau berkat ilahi. Dalam ilmu Pendidikan, peserta didik dan pendidik perlu memahami bahwa pikiran yang baik menimbulkan tindakan yang baik pula. Tindakan yang jahat akan menhasilkan pribadiyang jahat pula. Peserta didik diotivasi untuk melakukan sesuatu yang baik, dan tidak berlebihan untuk mendapatkan pujian, dan hormat.

${ }^{14}$ Rohani Siahaan, “Analisis Pengaruh Nyanyian Jemaat Terhadap Kualitas Ibadah Gereja Protestan di Indonesia bagian Barat (GPIB) Jemaat Bukit Zaitun Makassar," Jurnal Jaffray 11, no. 2 (October 2, 2013): 140-64, https://doi.org/10.25278/jj71.v11i2.82. 


\section{Daftar Pustaka}

Matheus, Jonathan, and Elisabet Selfina. "Peran Pembina Remaja Bagi Perkembangan Perilaku Remaja Di Gereja Kemah Injil Indonesia Tanjung Selor Kalimantan Utara.” Jurnal Jaffray 13, no. 1 (January 31, 2015): 1-22. https://doi.org/10.25278/jj71.v13i1.3.

Pahliwandari, Rovi. "Penerapan Teori Pembelajaran Kognitif Dalam Pembelajaran Pendidikan Jasmani Dan Kesehatan.” Jurnal Pendidikan Olahraga 5, no. 2 (March 18, 2017): 154-64. https://doi.org/10.31571/jpo.v5i2.383.

Ronda, Daniel. Dasar Teologi Yang Teguh: Panduan Teologi Sistematika Di Perguruan Tinggi. Makassar: Sekolah Tinggi Theologia Jaffray Makassar, 2013.

Sahiu, Sifra, and Hengki Wijaya. "Hubungan Motivasi Belajar Ekstrinsik Terhadap Hasil Belajar Psikomotorik Pada Mata Pelajaran Agama Kristen Kelas V Di SD Zion Makassar.” Jurnal Jaffray 15, no. 2 (September 22, 2017): 231. https://doi.org/10.25278/jj71.v15i2.262.

Siahaan, Rohani. "Analisis Pengaruh Nyanyian Jemaat Terhadap Kualitas Ibadah Gereja Protestan di Indonesia bagian Barat (GPIB) Jemaat Bukit Zaitun Makassar." Jurnal Jaffray 11, no. 2 (October 2, 2013): 140-64. https://doi.org/10.25278/jj71.v11i2.82.

Sutarto, Sutarto. "Teori Kognitif Dan Implikasinya Dalam Pembelajaran.” Islamic Counseling: Jurnal Bimbingan Konseling Islam 1, no. 2 (December 28, 2017): 1-26. https://doi.org/10.29240/jbk.v1i2.331.

Wijaya, Hengki. Analisis Data Kualitatif Ilmu Pendidikan Teologi. Makassar: Sekolah Tinggi Theologia Jaffray Makassar, 2018.

Wijaya, Hengki. Metode Penelitian Pendidikan Teologi. Makassar: Sekolah Tinggi Theologia Jaffray Makassar, 2013.

Wijaya, Hengki. "Pengenaan Manusia Baru Di Dalam Kristus: Natur, Proses, Dan Fakta Serta Implikasi Teologis Dan Praktisnya.” Jurnal Jaffray 14, no. 1 (March 22, 2016): 109. https://doi.org/10.25278/jj71.v14i1.194.

Wijaya, Hengki. "Ulasan Buku: Whatever Happened To Worship A Call To True Worship." Jurnal Jaffray 15, no. 1 (March 19, 2017): 148. https://doi.org/10.25278/jj71.v15i1.241.

Wijaya, Hengki, and Arismunandar Arismunandar. "Pengembangan Model Pembelajaran Kooperatif Tipe STAD Berbasis Media Sosial.” Jurnal Jaffray 16, no. 2 (October 6, 2018): 175-96. https://doi.org/10.25278/jj71.v16i2.302.

Wijaya, Hengki, and Helaluddin Helaluddin. Analisis Data Kualitatif Sebuah Tinjauan Teori \& Praktik. Makassar: Sekolah Tinggi Theologia Jaffray Makassar, 2019.

Wijaya, Hengki, and Helaluddin Helaluddin. "Hakikat Pendidikan Karakter," 2018. https://repository.sttjaffray.ac.id/id/publications/269450/hakikat-pendidikankarakter. 